\title{
THE ROLE AND UTILITY OF FINANCIAL AUDIT IN ROMANIA AND SPAIN - AN EMPIRIC STUDY
}

\author{
Ioana Iuliana Pop (Grigorescu) $)^{1}$ \\ Oana Raluca Ivan ${ }^{2}$
}

ABSTRACT: Our research includes the main results of an empiric study on the role and utility of the financial audit in Romania and Spain.

We undergone our research on a statistic population formed by the main three groups involved inf the financial audit process: the financial auditors, financial managers of the audited firms and the users of the audited accounting information. The main results of research, namely the questionnaire have been analysed with the help of Mann WhitneyTest, which has shown that for every statement the differences between the three groups from the two countries are significant. Next the results have been interpreted globally.

This way has been demonstrated the hypothesis according to which there are differences between perspectives and expectances between the pairs of groups the financial auditors, financial managers of the audited firms and the users of the audited accounting information in Romania regarding the role and utility of the financial audit.

Finally our study proposes solutions as how to meet the expectances of the three groups from Romania and Spain concerning the role and utility of the financial audit.

Keywords: empiric study, the role of the financial audit, the utility of the financial audit, differences of perspectives, differences of expectations.

JEL Code: $M 42$

\section{Introduction}

Worldwide the theme on the role of the audit has been of great interest and widely debated, in order to clarify the difficulties which come in understanding the social efficacy of the financial audit, as a lack of understanding the objectives, responsibilities or its limits.

The starting hypothesis of this research is the fact that there are differences of perspectives and expectations between the pairs of groups the financial auditors, financial managers of the audited firms and the users of the audited accounting information from Romania and Spain concerning the role, utility and the independence of the present financial audit.

In order to investigate this hypothesis we have proposed the following objectives of the research:

- Investigating the role and utility of the financial audit in Romania and Spain as seen by the financial auditors, managers of the audited firms and the users of the audited accounting information;

- Determining the significance of the differences of perspectives and expectations between the three groups from the two countries.

Identifying some closing possibilities of the expectations between the three groups.

\footnotetext{
1"1Decembrie 1918" University, Alba-Iulia, Romania, co-tutoring University Lleida, Spain, e-mail: ioanaiuliana69@yahoo.es

2 "1 Decembrie 1918" University, Alba-Iulia, Romania,e-mail: ivanralu@yahoo.com
} 


\section{Research methodology}

In order to investigate whether the hypothesis is confirmed or infirmed, but also to reach the objectives of the research we have choose to undergone an empiric research, a quantitative one.

We started by presenting the statistic population which will enter in the study. This way we have established the three groups interested in the work of the financial auditor to whom the questionnaire is addressed- financial auditors, financial managers of the audited firms and the users of the audited accounting information from Romania and Spain. According to the characteristics of the statistic population we have established the competence of the sample for each of the three groups, so that the results to be interpreted at the global level and to have a national relevance.

Table no. 1.

Statistic sample

\begin{tabular}{|l|c|c|c|c|c|c|}
\hline \multirow{2}{*}{} & \multicolumn{3}{|c|}{ ROMANIA } & \multicolumn{3}{c|}{ SPAIN } \\
\cline { 2 - 5 } & SENT & \multicolumn{2}{|c|}{ RECEIVED } & SENT & \multicolumn{2}{c|}{ RECEIVED } \\
\cline { 3 - 4 } \cline { 5 - 7 } & & $\begin{array}{c}\text { Absolute } \\
\text { value }\end{array}$ & Percent & & $\begin{array}{c}\text { Absolute } \\
\text { value }\end{array}$ & Percent \\
\hline AUDITORS & 600 & 211 & $35,17 \%$ & 1100 & 247 & $22,45 \%$ \\
\hline MANAGERS & 504 & 133 & $26,39 \%$ & 619 & 108 & $17,45 \%$ \\
\hline USERS & 492 & 157 & $32,30 \%$ & 514 & 149 & $28,99 \%$ \\
\hline TOTAL & 1596 & 501 & $31.28 \%$ & 2233 & 504 & $22,96 \%$ \\
\hline
\end{tabular}

As we can notice the percent of received answers from Romania was 31, 28\%, and from Spain 22, 96\%. Though the percent of the answers from Spain is inferior, its value is in the usual limits of these types of studies. The regular percentage of the received answers in Spain at this type of questionnaires is between 10\% and 20\% (Garcia Benau M.A. et al., 1993), we getting a superior percentage.

The specialty literature mentions that" the results of a research based on a questionnaire can be relevant if the answer is minimum 5\%" (Cernea, 2012) from the initial sample, the results being expandable for all the statistic population.

"For the obtained results by studying the sample to be extended at the level of the whole population, that sample must be representative, meaning it has to have all the basic characteristics of the population from which it has been extracted" (Opariuc-Dan, 2009). The same author states that:"the assurance of a sample is of maximum importance. The method that helps us select a sample from a population has implications on the validity and generalisation of the conclusions got after studying the sample".

When a simple is extracted at random, each unit of the statistic population has an equal possibility of entering in the content of the simple. It is the case of the financial auditors who entered in the composition of the samples from Romania and Spain, for which we have chosen the stratified random Method and the simple random Method. The process of stratification adds an extra element to the representation of the samples of the auditors.

In the case of the financial managers of the audited firms and of the users of audited financial information it couldn't be used the Random Method because it couldn't be established the "sample basis". In order for the samples to be representative this has been chosen logically based on the professional ratio, and for choosing effectively the unit of the samples we have used a random method, the systematic random, which functions with the help of a starting point and of a sample step. This method "offers to all the statistic units equal possibilities to enter the sample" (OpariucDan, 2009). 

samples.

We consider that using these methods of sampling offers representatively to the chosen

The questionnaire is anonymous and contains closed questions, positively formulated. To make the work easier for the person who fills in the form and to be able to quantify the answers we limited the answers to five, on a value scale from 1 to 5 , according to Likert Scale, where 1 represents the maximum level of agreement, 5 represents the maximum level of disagreement, 3 represents the neutral value and 2 and 4 intermediate values of agreement and disagreement. Only one single answer is to be given.

The process of sending and receiving the answers has been by e-mail, during FebruaryDecember 2012. The answers have been centralised by an informatics Excel programme, specially designed for it and interpreted with the help of econometric model Mann Whitney, which have shown if the differences for each statement of the questionnaire between the three pairs of groups involved categories are significant or not.

Also, the results of the tests have been incorporated inside some tables, which are the basis of the descriptive analyses of the questionnaire results.

\section{Literature review}

In the last years at the international level have been realised a lot of studies empiric and comparative concerning the financial audit. First of all we have to remind the fact that the European Commission has initiated a large process of consulting among the EU member countries concerning the role of the financial audit, the independence of the auditors, information given by the audit Report, concentrating the audit market inside Big Four or the problems connected to the corporative governance.

If we talk about the role and the utility of the financial audit there are researchers which state the fact that only if the financial audit hadn't been imposed to the firms as a legal obligation but as a voluntary one it could have been proved how appreciated its role is by the firms and users. Users of financial statements are recognized through their needs to be informed by the reliable financial statements, that have to disclose all the material information (Socol, 2008). Other studies sustain the necessity of the financial audit and its regulations by the professional organisms, considering the protection of the users on the capital markets (Ricol, 2008) and (Humphrey et al, 2009).

In what concerns the term "audit expectation gap" there are studies which sustain the necessity of educating the public regarding the limits of the financial audit (Fowzia, 2010) and (Porter, 2009).

In the last years have appeared studies which debate the role of the financial audit during the periods of the economic crises. This way are being analysed the characteristics of the audit committees from the firms affected by the crises and of those which haven't been affected (Rahmat et al., 2009), are exposed the challenges and opportunities which crises offers to the financial auditors (Fraser and Pong, 2009), or it is offered a reflection on the actual audit practices, specially referring to auditing new forms of investments and complex financial instruments (Sikka et al., 2009). Also, based on the found information from the managers of some financial institutions, it is analysed the present financial crises from the perspective of the corporative governance (Haspeslagh, 2010). The most recent is the study on the firm Price Waterhouse Cooper from 2011 which analyses the perception of the investors from England on the role and utility of the financial audit in the context of the actual economic crises.

In Romania we do not have many empiric studies on themes of financial audit. Still lately have appeared some specialty magazines, but generally they are reduced. Some examples might be: "The statistic explore of the audit market having as a purpose the appreciation of the auditor" (Jaba, Robu, 2011) and refers to the connection and direct effect which has on the independence of the auditor the financial performance of the audit firm; "The external auditors and the corporative 
governance under the impact of the financial crises" (Dobroțeanu et al., 2011) which treat the role of the external audit and of the corporative governance in credibility of the financial report of the firms; "The dynamic of the perceptions regarding the external audit under the impact of the financial crises" (Dobroțeanu et al., 2011) an empiric study about the degradation of the perceptions of a group of students on the problems "audit expectation gap" before starting the financial crises and after its starting; "The importance of the information offered by the financial audit for managers, investors and financial analysts" (Cernea, Ştefănescu, 2012) - an empiric study which refers to determining the degree of appreciation of the information delivered by the audit report by the users.

Expectations on the utility and the role of the financial audit in Spain are also analysed in empiric and comparative studies since the period immediately after entering of Spain in the EU (GarcíaBenau et al., 1993). In the last years has been analysed the role of the financial audit inside the small and middle firms (MartínezGarcía et al., 2010) or the role of the financial audit on the public foundations (GonzálesDíaz et al., 2011).

Years ago this type of study were specific to Anglo-Saxon countries, but today they have extended to all European countries, as they allow touching a better convergence between them.

\section{The econometric analyses of the obtained results}

Mann Whitney Test is a nonparametric test used only when there are to compare two independent groups. To analyse the data these have been transformed into ranks. The test has been used to evaluate if the differences at the ranks level are significant or not. The calculations have been made for each statement of the questionnaire.

The hypotheses associated to theMann Whitney Test are:

$H_{1}=$ there is a significant difference between the two groups

$H_{0}=$ there are NO significant differences between the two groups

In order to reject the null hypothesis $H_{0}$ we pass to calculating $\mathrm{U}$ on the following stages:

- Finding the rank of each result for both groups.

- Adding the ranks for each group

- calculating $\mathrm{U}$ which represents the minimum value between $U_{1}$ and $U_{2}$

$$
\begin{gathered}
\mathrm{U}=\min \left\{\begin{array}{ll}
U_{1} 1, & U_{1} 2
\end{array}\right\}, \\
U_{1}=N_{1} N_{2}+\frac{N_{1}\left(N_{1}+1\right)}{2}-R_{1} \quad \text { and } \\
U_{2}=N_{1} N_{2}+\frac{N_{2}\left(N_{2}+1\right)}{2}-R_{2}
\end{gathered}
$$

Where,

$N_{1}$ Is the number of observations from group 1

$\mathrm{N}_{2}$ Is the number of observations from group 2

$R_{1}$ Is the sum of the ranks in group 1

$R_{2}$ Is the sum of the ranks in group 2

Next we will calculate Z:

$$
\begin{aligned}
& \mathrm{Z}=\frac{U-\mu_{U}}{\sigma_{U}} \\
& \text { Where }^{\mu_{U}}=\frac{N_{1} N_{2}}{2} \text { and }^{\sigma_{U}^{z}}=\frac{N_{1} N_{2}\left(N_{1}+N_{2}+1\right)}{12}
\end{aligned}
$$


When the values repeat $\sigma_{U}^{2}$ will be given by the formula:

$\sigma_{U}^{2}=\frac{N_{1} N_{2}}{N(N-1)} x\left[\left(N^{\top} 3-N\right) / 12-\Sigma_{1}(j=1)^{\dagger} g \equiv \llbracket t_{1}\left(j^{3}-t_{j} j\right) / 12\right] \rrbracket$

Where,

$N=N_{1}+N_{3}$ and it represents the total of observations

$\mathrm{g}$ is the number of groups of repetitions

$t_{\text {f }}$ Is the number of repetitions in the group $\mathrm{j}$

The theoretical interpretation of the Test Mann Whitney is based on the table values of the Test $\chi^{2}$. The value of $Z$ obtained this way is compared to the critical table values from the normal curve corresponding to chosen $\alpha$ level, unilateral or bilateral. If the obtained $\mathrm{Z}$ is bigger than $\mathrm{Z}_{\alpha}$ from the table, at a significance threshold of minimum $\alpha=0,01$ or minimum $\alpha=0,05$ then the null hypothesis is rejected and it is demonstrated that there is a real difference, a significant one between the two groups.

1. An interpretation of the results, perspectives and expectances on the role and utility of the financial audit in Romania and Spain

One of the objectives of this research was to determine the significance of the differences between perspectives and expectations that exist between the three pairs of groups from Romania and Spain. The results of the Mann Whitney Test are as they come out from the table:

Table no. 2.

The significant differences between the pairs of groups of financial auditors, financial managers and users of audited accounting information in the two countries according to the Test Mann Withney

\begin{tabular}{|l|c|c|c|c|}
\hline & $\begin{array}{c}\text { Total } \\
\text { Statements }\end{array}$ & $\begin{array}{c}\text { Differences } \\
\text { between the } \\
\text { auditors in } \\
\text { Romania and } \\
\text { Spain }\end{array}$ & $\begin{array}{c}\text { Differences } \\
\text { between the } \\
\text { financial } \\
\text { managers in } \\
\text { Romania and } \\
\text { Spain }\end{array}$ & $\begin{array}{c}\text { Differences } \\
\text { between the users } \\
\text { in Romania and } \\
\text { Spain }\end{array}$ \\
\hline The role of the audit & 14 & 4 & 10 & 6 \\
\hline The utility of the audit & 20 & 16 & 13 & 11 \\
\hline T O T A L & $\mathbf{3 4}$ & $\mathbf{2 0}$ & $\mathbf{2 3}$ & $\mathbf{1 7}$ \\
\hline
\end{tabular}

Significant differences for a significance threshold of 5\% and $1 \%$

Source: own processing

This way it has been demonstrated the fact that there are differences between the perspectives and expectations between Romania and Spain regarding the role and the utility of the financial audit. The most important differences between the two countries that came out after analysing the results of the Test Mann Whitney refer to the following aspects:

The statement referring to the stakeholders of the audited accounting information generate a different ranking of preferences in the two countries. In Romania the first places are taken by the shareholders, followed by the financial entities, while in Spain on the first position are the financial analysts, followed by the shareholders and financial entities. The last position is taken in both countries by the employees. 
A strong polarisation of the answers in Romania and Spain is produced in the case of the statement that the financial audit brings "an added value" to the audited society. $83 \%$ respectively $77 \%$ of the auditors agree to it while the financial auditors do not agree. From here starts the disagreement for the following statement in which $77 \%$ respectively $72 \%$ from the auditors think that the cost of the financial audit is justified, while only $29 \%$ respectively $8 \%$ from the financial managers agree to this statement.

Referring to the statement "to expand the tasks of the auditor so that to allow him to pronounce on the efficacy of the way of managing, the next evolution of the firm, the profit of the firm and the solvency of the firm" we can say that they bring new differences of perspectives. In general the position of these financial auditors is to refuse new tasks, while, the other two groups express their expectances referring to the information that they would like to find in the Audit Report. The position of the three Spanish groups is more radical tan of the groups in Romania, which express the expectances in a moderate form. The percent of users of audited accounting information and of the Spanish financial managers who want to extend the tasks of the auditors is bigger in Spain tan in Romania. Also the percent of the financial auditors in Spain who do not accept the extending of their tasks is bigger in Spain than in Romania. Therefore we can say that the polarisation of the expectances on this theme is stronger in Spain than in Romania.

Referring to the statement that "The financial audit offers a better protection against fraud" we can say that in Romania there is a positive opinion, more optimistic than the one in Spain. As a similitude between the two countries we can state that the group of auditors and the one of users of audited financial information have expressed a higher agreement than the financial managers on the fact that the financial audit offers a better protection against fraud.

The statement about raising the compulsory audit limits has produced a lot of controversial discussions. $44 \%$ of the financial managers from Romania consider that the financial audit brings few benefits for a firm, and $60 \%$ consider that the financial audit lasts for too long, therefore it has high costs, therefore: $79 \%$ of the financial managers in Romania want raising the compulsory audit limits, and 59\% of the financial managers in pain do not want raising the compulsory audit limits.

These percents demonstrate once again the maturity of the audit market in Spain. Though in this country the compulsory audit limits are lower than in Romania, the power of buying is bigger and the firms touch easier these limits, they do not want their raising. In Romania, though the limits are higher, the power of buying is lower, so the firms touch harder the compulsory audit limits; the financial managers in Romania want their raising.

From here comes the fact that in Romania people don't know, are not aware of the fact that the financial audit has benefits on the audited financial information and on the economic environment in general, being compulsory the educating the public from this perspective.

As a result of analysing the results of the questionnaire we noticed that the national culture or the experience during the years in the field of financial audit in a country has a great influence on the professionals' experience. For example, $43 \%$ from the financial auditors in Romania agree to the fact that the financial audit is being made ONLY when it represents a legal obligation. In Spain the situation is different, as $44 \%$ from the financial auditors do not agree to this statement while $72 \%$ from the financial managers express no opinion.

We notice that in Romania almost half of the financial auditors are convinced that the financial audit is realised only if it represents a legal obligation, and the rest are convinced or cannot decide, and in Spain almost half are convinced that the financial audit is realised even if it does not represent a legal obligation, the others expressing no opinion or the disagreement. The statistics from this country show that $24 \%$ from the total of the made audits are voluntary (a quite important percent), and the rest represents a compulsory audit.

In Romania we did not find any statistic which would separate the voluntary audit from the compulsory one, but according to the financial auditors opinion there is a feeling of dissatisfaction towards the attitude of the firms in front of the voluntary audit. We notice that $46 \%$ from the 
financial managers in Romania declare that they call for the services of the audit only if it is compulsory, while in Spain only 13\% from the financial managers state this thing. In Romania this feeling that the audit is necessary will be won in time. Now it is still seen as something new, having a role and objectives still unclear.

To our knowledge in Romania still are important "the legal obligations", fact that it is compulsory and imposed. If there is a law no one talks much about it, they simply apply it. The role and the power of the state are not questioned or contested as they are in Spain.

In Spain it seems that over the role of the state is also imposed the role of the "market economy", of democracy. The citizens, professionals are accustomed to clearly express their dissatisfactions, needs and to be listened. From this reason the polarisation of the answers in Spain is higher than in Romania. The financial auditors do not give up the obtained rights, the already established tasks, while the financial managers and the users of the audited accounting information from Spain ask loudly than those in Romania changing the tasks of the financial auditors according to the new economic context and their new needs. It is a country where the democratic laws function, and the political powers represent the needs of the citizens.

As a support for my statement come the answers of the questioned ones when it refers to "who" uses the audited financial information. In a previous chapter we have realised a hierarchy of the users of audited accounting information from the two countries. We notice that in Romania the state occupies the forth place as user of audited accounting information, while in Spain the state occupies only the seventh place. In Spain the first place is occupied by the public opinion, which in Romania occupies only the third place. It results that in Spain the role of the state is placed in the service of the public opinion, to support and serve the public opinion, while in Romania it seems that the role of the citizens is only that of applying the laws imposed by the state.

Next we will try to relate the statements inside the questionnaire and to underline a series of particularities noticed as a result of the global analyses of the answers. We want for this research to go further from the own meaning of the obtained values as an answer to the established statements inside the questionnaire and to underline new ideas and perspectives on the profession of auditor in Romania and Spain.

If we talk about the perspectives that the financial managers and the users of the audited accounting information from the two countries have on the legal responsibilities of the auditors, we can say that part of them have demonstrated that they do not know the present legal norms. The situation is as follows:

- $\quad 48 \%$ of the financial managers in Romania

- $63 \%$ of the users of the audited financial information in Romania

- $48 \%$ of the financial managers in Spain

- $65 \%$ of the users of the audited financial information in Spain

think that is the responsibility of the financial auditor to detect the fraud and errors in the audited firm.

- $15 \%$ of the financial managers in Romania

- $16 \%$ of the users of the audited financial information in Romania

- $13 \%$ of the financial managers in Spain

- $18 \%$ of the users of the audited financial information in Spain

considers that it is the responsibility of the financial auditor doing the financial situations that are to be audited.

- $23 \%$ of the financial managers in Romania

- $23 \%$ of the users of the audited financial information in Romania

- $\quad 45 \%$ of the financial managers in Spain

- $\quad 47 \%$ of the users of the audited financial information in Spain

considers that it is the responsibility of the financial auditor the revise of the accounting of the audited firm. 
Along the research it has been noticed a disagreement to the legal present norms. As it will be shown in the presentation of the following percents, part of the financial managers of the audited firms and the users of the audited accounting information express the disagreement to the legal norms which establish the tasks of the auditors:

- $31 \%$ of the financial managers in Romania

- $34 \%$ of the users of the audited financial information in Romania

- $46 \%$ of the financial managers in Spain

- $50 \%$ of the users of the audited financial information in Spain

declares that there is a feeling of dissatisfaction from them regarding the role and the legal objectives of the financial auditor. Part of these declares that they would expand the tasks of the auditor this way:

- $35 \%$ of the financial managers in Romania

- $56 \%$ of the users of the audited financial information in Romania

- $23 \%$ of the financial managers in Spain

- $\quad 49 \%$ of the users of the audited financial information in Spain

declares that they would expand the tasks of the auditor so that to allow him to pronounce inside the Audit Report on the efficacy of the managing the audit firm.

- $50 \%$ of the financial managers in Romania.

- $67 \%$ of the users of the audited financial information in Romania

- $34 \%$ of the financial managers in Spain

- $\quad 47 \%$ of the users of the audited financial information in Spain

declares that they would expand the tasks of the auditor so that to allow him to pronounce inside the Audit Report on the future evolution of the audited firm.

- $25 \%$ of the financial managers in Romania

- $41 \%$ of the users of the audited financial information in Romania

- $23 \%$ of the financial managers in Spain

- $39 \%$ of the users of the audited financial information in Spain

declares that they would expand the tasks of the auditor so that to allow him to pronounce inside the Audit Report on the profitability of the audited firm.

- $59 \%$ of the financial managers in Romania

- $64 \%$ of the users of the audited financial information in Romania

- $29 \%$ of the financial managers in Spain

- $\quad 40 \%$ of the users of the audited financial information in Spain

declares that they would expand the tasks of the auditor so that to allow him to pronounce inside the Audit Report on the solvency of the audited firm.

Next we will present a synthesis of the perceptions of the users in Romania and Spain on the work of the financial auditors.

Part of the financial managers of the audited firms and of the users of the audited financial information in Romania and Spain has manifested perspectives pretty negative on the exposed themes inside the questionnaire. For example,

- $60 \%$ of the financial managers in Romania

- $38 \%$ of the users of the audited financial information in Romania

- $29 \%$ of the financial managers in Spain

- $\quad 43 \%$ of the users of the audited financial information in Spain

think that the financial audit mission lasts long, and

- $\quad 46 \%$ of the financial managers in Romania

- $13 \%$ of the users of the audited financial information in Romania

- $\quad 47 \%$ of the financial managers in Spain

- $16 \%$ of the users of the audited financial information in Spain

considers that the cost of the financial audit it is not justified. Also, 
- $\quad 44 \%$ of the financial managers in Romania

- $19 \%$ of the users of the audited financial information in Romania

- $\quad 42 \%$ of the financial managers in Spain

- $\quad 8 \%$ of the users of the audited financial information in Spain

have declared that realising an audit mission has few benefits for a firm, and

- $22 \%$ of the financial managers in Romania

- $26 \%$ of the users of the audited financial information in Romania

- $43 \%$ of the financial managers in Spain

- $36 \%$ of the users of the audited financial information in Spain

considers that the financial audit does not offer a better protection against fraud.

As a conclusion for choosing this cause we could add the fact that

- $31 \%$ of the financial managers in Romania

- $34 \%$ of the users of the audited financial information in Romania

- $\quad 46 \%$ of the financial managers in Spain

- $50 \%$ of the users of the audited financial information in Spain

declares openly that there exists from them a feeling of dissatisfaction regarding the role and the legal objectives of the financial auditor

In the actual economic context we can say that the perception of the financial auditor on his own work has suffered modifications. The answers at the questionnaire demonstrate a series of surprises from this perspective: $16 \%$ of the financial auditors in Romania and $29 \%$ from Spain do not consider that the users of the audited accounting information expect "too much" from them.

Also, $43 \%$ from the financial auditors in Romania and 34\% from Spain are aware and admit the fact that there is a feeling of dissatisfaction from the users of audited accounting information regarding the role and the legal objectives of the financial audit.

In these conditions, more and more auditors give up at the tasks of the users of the audited accounting information to extend the area of the legal attributions

\section{Conclusions}

As a conclusion we think that it is necessary a closing of the positions of the financial auditors with that of the users of the audited accounting information. What is to be seen anyway is the fact that in Romania the positions are not as strong, there is not a strong polarisation of the answers (the average value does not closet o 1 nor by 5, but the majority are between 2 and 4). This thing shows the fact that there are problems and in satisfactions regarding the role and utility of the financial audit, there is a feeling of in satisfaction from the users, but they are aware of his existence by the financial auditors.

We also, think that it is necessary a reconsideration of the responsibilities of the financial auditors, meaning accepting of new responsibilities according to the expectations of the users and the new economic context and a more correct information of the public on the legal responsibilities of the financial auditors and on the limits of this profession.

The actual differences of perspectives determine future expectations on the auditors "work. As global analyses of the answers from the questionnaire we have divided expectations of the users of audited accounting information in two categories: realistic and non-realistic.

The study of the financial audit and of the perspectives and expectations that exist about it has generated discussions in the last thirty years. The research realised by the help of the test Mann Whitney allowed demonstrating the fact that there are differences between perspectives and expectances between Romania and Spain regarding the role and the utility of the financial audit

Regarding identifying some closing possibilities of the expectances between the three pairs of groups we propose two solutions: in case in which the expectances are realistic, but the attributions are not comprised in the actual legal norms of the financial auditors, we propose MODIFYING THE LEGAL NORMS IN AGREEMENT TO THE ACTUAL NECESITIES, and in 
case in which the expectances are non-realistic we propose EDUCATING THE PUBLIC, as to reduce these differences between perspectives and expectances.

As measures of educating the public we propose to the Chamber of the Financial Auditors in Romania and to the Accounting and Audit Institute from Spain realising actions that will lead to spreading and knowing the legal norms referring to the financial audit, of the real tasks of the auditors and of the importance of the work realised by them both for the audited firm and for the different categories of users. Examples of these kinds of actions can be:

- Participating frequently of the representatives CAFR and ICAC to radio shows or broadcasted economic shows, destined to the Romanian entrepreneurs, to the users of audited accounted information but to the public too, in which they will make themselves public and to insist on the real tasks of the financial auditors;

- Participating frequently of the representatives CAFR and ICAC to different conferences, professional trainings, seminars and debates to which also participate representatives of the Romanian and Spanish firms or professionals from the investment domain, banking or assurance, etc to make known the aspects connected to the tasks and responsibilities of the auditors;

- Cooperating continuously with the Professional Associations and the Patronage Associations from the domains interested in the work of the financial auditors to permanently informing the members regarding the tasks, responsibilities and the importance of the work of the financial auditors.

The financial audit has progressed and perfection itself at the same time to the economic development, as an answer to the society challenges, It has progressed from the historical point of view, being present in a certain form in all the periods, from the concept point of view and mostly from the objectives point of view. Therefore we believe that the auditors and the audit firms shouldn't pass over the social importance that is given today to the financial audit, the position obtained today in the society after hundreds of years of efforts and to enlarge the area of responsibilities, look for new methods or procedures compatible to the actual needs, which would come in the users support.

\section{References}

1. Blasco. J., 2004. The audit Report and its expectances, Partida Doble Magazine, November, pp. $22-26$

2. C.E.C.A.R., 2005. The National Ethic Code of the Professional Counters in Romania, Bucure $\square \mathrm{ti}$

3. Cernea O., Ştefănescu C.A1., 2012. The importance of the offered information by the financial audit for the managers, investors and financial analysts, Financial Audit Magazine, pp. 42-50

4. Citron, D.B., Taffler R.J., Uang J.Z., 2008. Delays in reporting price - sensitive informacion: The case of going concern, Journal of Accounting and Public Policy, nr. 27, pp 19-37

5. Directive nr. 2006/43/CE of the European Parliament from May 17th 2006 of 17 may 2006, referring to the legal audit of the financial situations and annual consolidated accounts, which modifies the Directives IV and VII and abolishes the Directive 84/253/CEE, published in the Official Journal of the European Union no. 157/9 June 2006

6. Dobroțeanu L., Coman N., Dobroțeanu C.L., 2011. The external auditors and the corporative governance under the impact of the financial crises, pp. 16-26

7. Dobroțeanu L.,Manea D., Dobroțeanu C.L., 2011. The dynamic of the perceptions regarding the external audit under the impact of the financial crises, Financial Audit Magazine, pp.1827 
8. Domni $\square$ oru S., Briciu S.; Popa I.E., Bunget O.C., 2010. Statutory audit versus financial communication. Why and how?, Financial Audit Magazine, no. 7, pp. 3-13

9. Domni $\square$ oru S., 2011. Statutory audit and financial communication, vol. I, Economic Publishing House, Bucharest

10. European Commision, oct. 2010. Green Paper - Audit policy: lessons from the crisis, http://ec.europa.eu/internal_market/auditing/docs/market/consultation2008/summary_report _en.pdf

11. European Commission, Authorised contributions to be edited regarding the Green Book of the European Commission from October $13^{\text {th }} 2010$ the audit policy: lessons of crises and the summary of these contributions, http://ec.europa.eu/internal_market/consultations/2010/ green_paper_audit_en.htm, accessed on March $3^{\text {th }} 2011$

12. European Commission, The Recommendation of the Commission from May $16^{\text {th }} 2002-$ the independence of the statutory audit in E.U. a set of fundamental principles, http://eurlex.europa.eu/LexUriServ/LexUriServ.do?uri=OJ:L:2002:191:0022:0057:EN:PDF, accessed on October $15^{\text {th }} 2012$

13. European Committee and Socio-Economic, A preliminary project of the study group "the audit policy" regarding the Green Book "The audit policy: lessons of crises" debated in the public meeting on April $28^{\text {th }} 2011$, Brussels, http ://www.eecs.europa.eu, accessed on October $5^{\text {th }} 2011$

14. European Committee and Socio-Economic, The agreement regarding the Green Book "The audit policy: lessons of crises" edited in the Official Journal of the European Union number 248/92 from August $28^{\text {th }}$ 2011, http://www.eecs.europa.eu, accessed on March $2^{\text {th }} 2012$

15. European Committee and Socio-Economic, The agreement regarding the Directive proposal of the European Parliament and of the Council of modifying the Directive 2006/43/CE on the legal audit of the annual accounts and of the consolidated accounts and the proposal of Regulation of the European Parliament and of the Council regarding specific tasks to the statutory audit of the public interest entities, Official Journal of the European Union C $191 / 61$, of June $29^{\text {th }} 2012$,

16. http://eurlex.europa.eu/LexUriServ/LexUriServ.do?uri=OJ:C:2012:191:0061:0071:RO:PDF, accessed on October $5^{\text {th }} 2012$

17. Fowzia, R., 2010. An empirical Study on Audit Expectation Gap: Role of auditing Education in Bangladesh, on line at http://mpra.ub.uni-muenchen.de/22708/, MPRA Paper No. 22708

18. García Benau M.A., Humphrey C., Moizer P., Turley S., 1993. Audit and its expectances: Spain and United Kingdom, ICAC Publishing House, Madrid

19. Government Emergency Ordinance number 75/1999 regarding the activity of financial audit re-edited according art. III from the Government Ordinance no. 67/2002, published in the Official Monitor of Romania Part I, no. 649 from August 31st 2002, the texts being given a number

20. Government Emergency Ordinance number 90, from June 24th 2008 regarding the statutoryaudit of the annual consolidated financial situations, published in the Official Monitor of Romania, no. 481 from June 30th 2008

21. Haspeslagh, P., 2010. Corporate governance and the current crisis, Corporate Governance, Volume 10, Issue 4

22. Fraser I., Pong C., 2009. The future of the external audit function, Managerial Auditing Journal, Vol. 24, Issue 2, pp.104 - 113

23. International Federation of Accountants, 2009. Manual of International Standards of Quality Control in Audit- Financial Audit, Irecson Publishing House, Bucharest

24. Iona $\square$ cu I. 2007. Epistemology of the accounting, Economic Publishing House, Bucharest 
25. Jaba E., Robu I.B., 2011. Exploring the statistics of the audit market as to appreciate the auditor, The financial audit magazine, pp. 28-36

26. Law nr. 26 from 2010 to modify and complete O.U.G. no. 75/1999 regarding the activity of Financial audit in Romania, published in the Official Monitor of Romania, Part I, no. 145 from March 5th 2010

27. Lee R.D., Johnson R.W., Joyce P.D., 2009. Budgeting the public systems, Jones\&Bartlett Learning Publishing House, Sudbury, Massachusetts, USA

28. Liggio C.D., 2011. The expectation gap: The Accountant's Legal Waterloo, Journal of Contemporary Business, nr. 3, vol. 3, pag. 27-44, quoted by Block

29. Manchado de Almeida Muñoz C., 2008. The evidence of expectances in the audit of markets of low dimensions: the Portuguese case, Revista de Contabilidad y Financas - UPS, vol.19, no. 47, pp. 102-111

30. Monterrey Mayoral J.A., Sánchez Segura A., 2007. An empiric study on the auditor's fees, Cuadernos de Economía y dirección de empresa, no. 32, pp. 81-110

31. Phillips R., Freeman R.E., Wicks A.C., 2003. What stakeholder theory is not, Bussines Ethics Quarterly, 13(4), pp. 479-502

32. Porter B.A., 2003. The Audit Expectation-Performance-Gap and the Roll of External Auditors in Society, NewZeeland, 1990, quoted by Bahr

33. Porter B., Hogartaigh O., Baskerville C., Report of research conducted in the United Kingdoom and New Zeeland in 2008 investigating the audit expectation-performance gap and users' understanding of, and desired improvements to, the auditors report's reports, September 2009, www.ifac.org

34. PriceWaterhouse Cooper UK, 2011. Study "Audit Today and Tomorrow", http://www.pxc.uk/eng/publications/audit-today-tomorrow-investor-survey.htlm

35. Rahmat M.M., Iskandar T.M., Saleh N.M., 2009. Audit committee characteristics in financially distressed and non-distressed companies. Managerial Auditing Journal, Vol. 24, No. 7, pp. 624-638

36. Sierra Molina G., Orta Pérez M., 2005. The experience and the ethic behaviour of the auditors: an empiric study, Revista Española de Financiación y contabilidad, vol. XXXIV, no. 126, July- September 2005, pp. 731-754

37. Sikka, P., Filling, S., Liew, P., 2009. "The Audit Crunch: Reforming Auditing”, Managerial Auditing Journal, 24(2), pp. $135-155$

38. Socol A., 2008. Materiality in the context of an audit between professional judgment and subjectivism, Anals of the University of Petroşani, Economics, vol. VIII, Part II, pp. 209-217

39. Spiegel R. Murray, Stephens J. Larry, 2009. Statistic, McGrav-Hill Interamericana Publishing House, Mexico

40. Tabără N., Briciu S., 2012. Actualities and perspectives in accounting and market control, Tipo Moldova House, Ia $\square \mathrm{i}$ 